\title{
Rapid protein A assay for intrinsic factor and its binding antibody
}

\author{
N A SOURIAL From the Department of Haematology, St Bartholomew's Hospital and Medical College, \\ London
}

SUMMARY A simple and rapid method for the measurement of cobalamin bound intrinsic factor (Cbl-IF) complex and intrinsic factor binding antibody is described. The method is based on the principle of affinity chromatography and adapted to a batch separation technique. A specific ligand staphylococcal protein A was coupled to Sepharose to form a convenient solid phase matrix. The intrinsic factor binding antibody in patients with pernicious anaemia was used to form an immune complex with Cbl-IF. This complex was adsorbed on to staphylococcal protein A. Gastric juice from control subjects and patients with pernicious anaemia was assayed for intrinsic factor activity and the results correlated very closely with two other established methods. Sera from 30 control subjects were assayed for binding intrinsic factor antibody and all were found to be negative; of 15 patients with pernicious anaemia, six were positive. These patients were selected with blocking antibody. The method does not require technologically advanced protein separation techniques and could therefore be applied in any clinical laboratory using radioisotopes. It could also be adapted to assay cobalamin in body fluids or in food.

The measurement of cobalamin bound intrinsic factor (Cbl-IF) complex is important in the study of the physiology and pathology of $\mathrm{Cbl}$ absorption. Although there are simple and rapid methods for measuring free intrinsic factor,$^{1-3}$ the available methods for measuring Cbl-IF are either tedious or not suited to assaying large numbers of samples. ${ }^{4-8} \mathrm{~A}$ simple and specific method for measuring Cbl-IF was therefore developed, adapting the principle of affinity chromatography to a batch assay separation technique. The specific ligand used was staphylococcal protein $\mathrm{A}$, which binds specifically to the $\mathrm{Fc}$ region of IgG molecules. ${ }^{910}$ There are two types of intrinsic factor antibodies which are directed towards different antigenic sites on the intrinsic factor molecule: a blocking antibody which blocks the attachment of $\mathrm{Cbl}$ to intrinsic factor; and a binding antibody which binds to intrinsic factor or IF-Cbl complex. The binding antibody to intrinsic factor found in some patients with pernicious anaemia was used to form an immune complex with IF-Cbl. This complex is adsorbed on to staphylococcal protein A agarose gel, which forms a convenient solid phase matrix. This method can be used to measure intrinsic factor, antibody to intrinsic factor, and $\mathrm{Cbl}$.

This paper describes the staphylococcal protein A

Accepted for publication 1 December 1987 method for the assay of IF-Cbl and for the screening of patients with pernicious anaemia for the presence of binding antibody to intrinsic factor. The intrinsic factor assay results were compared with those from two established methods, ${ }^{23}$ one using the blocking antibody to intrinsic factor and another using cobinamide (Cbi) which binds almost exclusively to $\mathbf{R}$ protein and not to intrinsic factor." Control samples of gastric juice were also assayed for intrinsic factor by gel filtration chromatography. ${ }^{512}$

Preliminary results of this work were presented at the International Society of Haematology congress in Sydney in 1986.

\section{Material and methods}

PROTEIN A-SEPHAROSE CL-4B

Staphylococcal protein A covalently coupled to Sepharose by the cyanogen bromide method (Pharmacia Fine Chemicals AB, Sweden) was swollen in $10 \mathrm{mM}$ phosphate buffered saline (PBS), pH 8.0, containing $0.1 \%$ sodium azide and stored at $4^{\circ} \mathrm{C} .{ }^{13}$ Before use the gel was washed in a sintered funnel with $0.1 \mathrm{M}$ sodium citrate/citric acid ( $\mathrm{pH} \mathrm{3.0)}$, containing azide $0 \cdot 1 \%$, to free any bound material and was then equilibrated at $\mathrm{pH} 8 \cdot 0$. The gel can be used repeatedly without appreciable deterioration. The protein A content of the swollen gel was $2 \mathrm{mg} / \mathrm{ml}$ and the binding capacity for human IgG was about $25 \mathrm{mg} \mathrm{IgG/ml} \mathrm{gel.}$ 
ALBUMIN COATED CHARCOAL

Charcoal suspension was prepared as described. ${ }^{2}$ Activated acid washed charcoal was obtained from BDH Chemicals Ltd and $20 \%$ solution of bovine albumin from the Blood Group Reference Laboratory, Oxford.

$\mathrm{CN}^{57}$ (CO) $\mathrm{CBL}$

$\mathrm{CN}^{57}$ (Co)Cbl $(200 \mu \mathrm{Ci} / \mu \mathrm{g}, \quad 7 \cdot 4 \quad \mathrm{MBq} / \mu \mathrm{g}) \quad$ was obtained from Amersham International. This was diluted with non-radioactive $\mathrm{CN}-\mathrm{Cbl}$ to give a solution of $10 \mu \mathrm{g} / \mathrm{l}$, specific activity $0.5 \mu \mathrm{Ci} / \mu \mathrm{g}(18.5 \mathrm{kBq} /$ $\mu \mathrm{g})$. The solution was checked for $\mathrm{Cbl}$ content using Euglena gracilis assay ${ }^{14}$ for purity using column chromatography and stored in the dark at $4^{\circ} \mathrm{C}$.

\section{GASTRIC JUICE}

Gastric juice specimens from 10 healthy subjects and two patients with pernicious anaemia were used. The latter two specimens were obtained without pentagastric stimulation during routine investigations. Eight of the 10 specimens from healthy subjects were kindly donated by Dr Russell Bayly (Amersham International); the remaining two, which were used as controls, were collected from two healthy volunteers who were members of staff at St Bartholomew's Hospital. Gastric juice from healthy subjects was aspirated at 15, 20, and 45 minutes after an intramuscular injection of pentagastrin $(6 \mu \mathrm{g} / \mathrm{kg})$ was given. The juice was filtered and the $\mathrm{pH}$ adjusted to 10.0 with $1 \mathrm{~N} \mathrm{NaOH}$ to inactivate the pepsin and 30 minutes later brought down to $\mathrm{pH} 7 \cdot 4$ with $1 \mathrm{~N}$ hydrochloric acid. The juice was stored in small aliquots at $-20^{\circ} \mathrm{C}$ until further use.

\section{INTRINSIC FACTOR ANTIBODY}

Sera from five patients with pernicious anaemia, all containing blocking antibody to intrinsic factor, were screened ${ }^{15}$ for binding antibody to intrinsic factor and two were found to be positive. One of these was used throughout this study.

Sera from 30 healthy subjects and 15 patients with pernicious anaemia were studied.

\section{SEPHACR YL-S200 COLUMN CHROMATOGRA PHY}

Column chromatography was used to measure intrinsic factor activity in control gastric juice. The separation of intrinsic factor from R-protein is improved by incubating the gastric juice with serum containing binding antibody to intrinsic factor before loading the sample on to the column. The Cbl-intrinsic factorantibody complex then elutes in the excluded volume before the R-protein. ${ }^{12}$ Gastric juice $(100 \mu \mathrm{l})$ was incubated with $\mathrm{CN}^{-57}(\mathrm{Co}) \mathrm{Cbl}$ one and a half times its predetermined binding capacity for 20 minutes at room temperature; $200 \mu \mathrm{l}$ of antibody serum was then added and incubated for a further 20 minutes; the mixture was then cooled and applied to $2.5 \times 100 \mathrm{~cm}$ column of Sephacryl-S200 (Pharmacia Fine Chemicals).

Columns were equilibrated and eluted at $4^{\circ} \mathrm{C}$ with

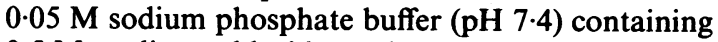
$0.5 \mathrm{M}$ sodium chloride and $0.02 \%$ sodium azide. Fractions $(4 \mathrm{ml})$ were collected and the radioactivity of each fraction was determined in a well type gamma scintillation spectrometer. The amount of radioactivity in the protein peaks was converted to picograms of band $\mathrm{CN}^{-57}(\mathrm{Co}) \mathrm{Cbl}$ using the appropriate specific activity.

\section{PRELIMINARY INVESTIGATIONS}

Combination of binding antibody with Cbl-IF complex Adding increasing amounts of Cbl-IF complex to a constant amount of antibody. These experiments were carried out using small amounts of Cbl-IF complex which are not sufficient to saturate the amount of antibody used. Four tubes were set up for each amount of Cbl-IF tested. Buffer at pH 8.0 (400 $\mu \mathrm{l}), 5 \mu \mathrm{l}$ of $20 \%$ bovine albumin, and $80 \mu \mathrm{l}$ of $\mathrm{CN}^{57}$ (Co)Cbl were added to each tube to saturate all binding sites of gastric juice. Increasing amounts of gastric juice 5,10 , $15,20,25,30 \mu \mathrm{l}$ were pipetted and the tubes incubated at room temperature for 20 minutes. To two of the four tubes $35 \mu$ l of serum containing antibody was added, and normal serum or buffer was added to the remaining two tubes. These served as control tubes to determine the non-specific binding. After the addition of $500 \mu \mathrm{l}$ of staphylococcal protein A the tubes were incubated at $4^{\circ} \mathrm{C}$ for 20 minutes washed twice in buffer (pH 8.0) and the radioactivity of the pelleted gel counted.

Adding increasing amounts of antibody to a constant amount of Cbl-IF complex. The effect of adding excessive amounts of antibody to a limited amount of $\mathrm{Cbl}-\mathrm{IF}$ was tested. The tubes were set up in triplicate and $400 \mu \mathrm{l}$ of buffer, $5 \mu \mathrm{l}$ of $20 \%$ albumin, and $25 \mu \mathrm{l}$ of $\mathrm{CN}-\left({ }^{57} \mathrm{Co}\right) \mathrm{Cbl}$ were added. After the addition of $10 \mu \mathrm{l}$ of gastric juice the tubes were incubated at room temperature for 20 minutes. To a duplicate set of tubes $5,10,15,20,30,35,40,45,50 \mu \mathrm{l}$ of serum containing antibody was added and control serum was added to the remaining set of tubes. The subsequent steps were as described above.

\section{ASSAY OF INTRINSIC FACTOR USING}

STAPHYLOCOCCAL PROTEIN A

The scheme for the assay of Cbl-IF using staphylococcal protein A-Sepharose is summarised in table 1. The tubes were incubated at room temperature for 20 minutes after each addition of $\mathrm{CN}\left({ }^{57} \mathrm{Co}\right) \mathrm{Cbl}$ and serum containing antibody. The added $\mathrm{CN}\left({ }^{57} \mathrm{Co}\right) \mathrm{Cbl}$ and antibody were both in excess of the anticipated 
Table 1 Protocol for protein A-sepharose assay for intrinsic factor

\begin{tabular}{|c|c|c|c|c|c|c|}
\hline Tube No & $\begin{array}{l}10 \mathrm{mM} \\
\text { Phosphate buffer } \\
\text { pH } 8.0(\mu l)\end{array}$ & $\begin{array}{l}20 \% \\
\text { Bovine albumin } \\
(\mu l)\end{array}$ & $\begin{array}{l}\text { Sample gastric } \\
\text { juice }(\mu l)\end{array}$ & $\begin{array}{l}\mathrm{CN}\left({ }^{57} \mathrm{Co}\right) \mathrm{Cbl} \\
(3 \mathrm{ng})\end{array}$ & $\begin{array}{l}\text { Antibody } \\
\text { or control } \\
\text { serum }(\mu l)\end{array}$ & $\begin{array}{l}\text { Protein A } \\
\text { Sepharose } \\
(I / 2)(\mu l)\end{array}$ \\
\hline $\begin{array}{l}1,2 \\
3,4 \\
5,6\end{array}$ & $\begin{array}{l}400 \\
400 \\
400\end{array}$ & $\begin{array}{l}20 \\
20\end{array}$ & $\begin{array}{l}10 \\
10\end{array}$ & $\begin{array}{l}30 \\
30 \\
30\end{array}$ & $\begin{array}{l}35 \\
35\end{array}$ & $\begin{array}{l}500 \\
500\end{array}$ \\
\hline
\end{tabular}

binding sites of the gastric juice and intrinsic factor, respectively. To facilitate pipetting, staphylococcal protein $A$ was diluted $1 / 2$ in buffer before being added to the assay tubes. All the tubes were subsequently incubated at $4^{\circ} \mathrm{C}$ for 20 minutes, centrifuged, and the gel washed twice in the buffer. The gel-pellet was counted in a well-type scintillation counter. The average counts of tubes 5 and 6 containing control serum were subtracted from the average counts of tubes 3 and 4 containing the antibody serum. The amount (ng) of bound $\mathrm{CN}\left({ }^{57} \mathrm{Co}\right) \mathrm{Cbl}$ was calculated as follows:

$$
\frac{\text { Sample counts (antibody) }- \text { control counts }}{\text { Total counts }- \text { background }} \times 3 \mathrm{ng}
$$

This represents the amount of $\mathrm{CN}\left({ }^{57} \mathrm{Co}\right) \mathrm{Cbl}$ bound to intrinsic factor in the sample.

Intrinsic factor in gastric juice samples was measured by two methods - that of Gottlieb et al $^{2}$ and that of Begley and Trachenberg. ${ }^{3}$ These methods require the blocking antibody to intrinsic factor and $\mathrm{Cbi}$, respectively. Serum from one patient with pernicious anaemia, with a high titre of blocking antibody, and Cbi Dicyanide (Sigma Chemicals) were used. The two control gastric juice samples were also assayed for intrinsic factor using column chromatography.

\section{ASSAY OF BINDING ANTIBODY TO INTRINSIC FACTOR IN SERUM}

To $400 \mu$ l of buffer (pH 8.0) was added $5 \mu$ l of $20 \%$ bovine albumin, $20 \mu \mathrm{l}$ gastric juice, and $50 \mu \mathrm{l} \mathrm{CN}$ ${ }^{57}(\mathrm{Co})-\mathrm{Cbl}$. The tubes were incubated for 20 minutes at room temperature and $50 \mu \mathrm{l}$ of serum was added (positive reference with high titre antibody, negative control, or the unknown sample). Staphylococcal protein A slurry $(500 \mu \mathrm{l})$ was added and the tubes incubated for 20 minutes at $4^{\circ} \mathrm{C}$, centrifuged at $1000 \mathrm{~g}$, the gel washed once in buffer, and the pelleted gel counted. When the average counts obtained with the patient sample was at least twice as high as the counts obtained with the negative control, the assay was positive for the presence of intrinsic factor antibody in the patient serum. If a quantitative measurement is needed then two washes should be performed and the non-specific binding taken into account. The average counts of the negative control were subtracted from the average counts containing the antibody serum. The amount (ng) of $\mathrm{CN}^{57}(\mathrm{Co}) \mathrm{Cbl}$ bound to intrinsic factor was calculated as follows:

$$
\frac{\text { Sample counts (antibody) - control counts }}{\text { Total counts - background }} \times 5 \text { ng }
$$

Fig 1 shows that over the range tested, the relation between antibody and Cbl-IF complex was linear, so that Cbl-IF measurements could be made without performing a series of standards. Furthermore, excess antibody did not appreciably affect the results (fig 2). The non-specific binding in the tubes containing control serum or buffer was similar. This was usually less than $1 \%$ and never exceeded $2 \%$ of the total count when the gel was washed twice. After one wash the non-specific binding averaged $3 \%$ and did not exceed $3 \cdot 5 \%$.

\section{Results}

COMPARISON OF STAPHYLOCOCCAL PROTEIN A, BLOCKING ANTIBODY, AND CBI ASSAY

Table 2 shows the results obtained by these three

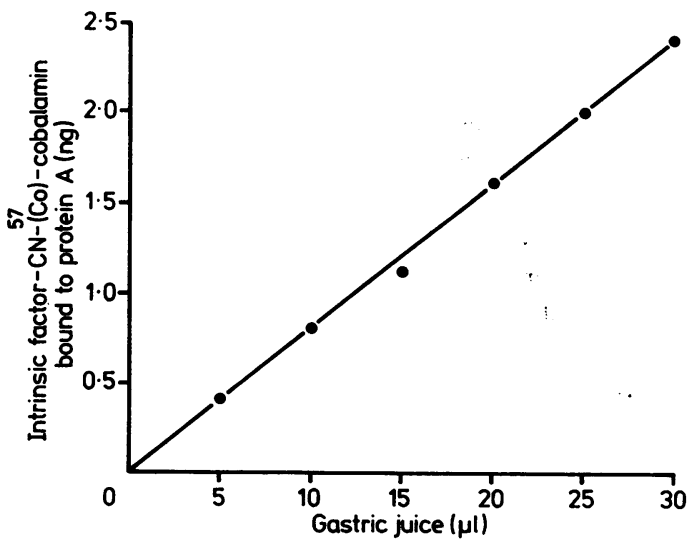

Fig 1 Relations between increasing amounts of gastric juice containing excess $C N-{ }^{57}(\mathrm{Co}) \mathrm{Cbl}$ and amount of IF-CN- ${ }_{-}^{57}$ (Co) Cbl complex bound to staphylococcal protein $A$. 


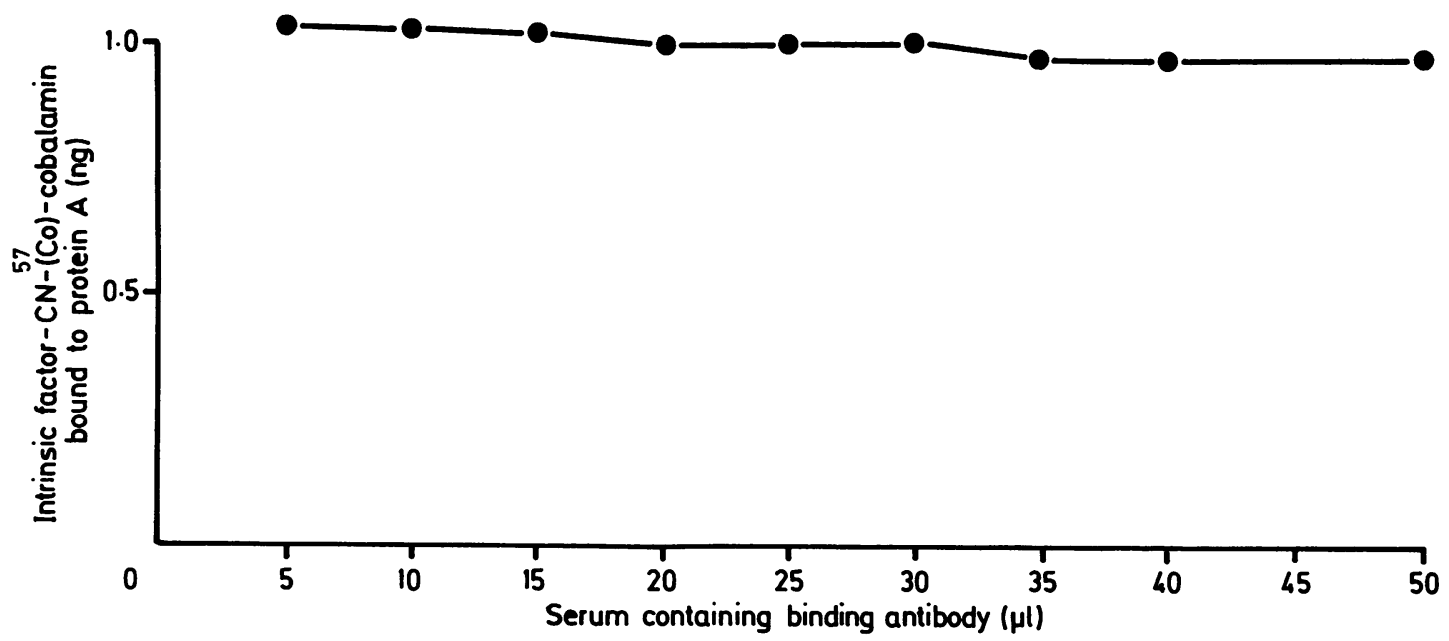

Fig 2 Amount of Cbl-IF complex bound to staphylococcal protein A in presence of excess binding antibody.

different intrinsic factor assays. There was good agreement between the results. The correlation between staphylococcal protein $\mathbf{A}$ and blocking intrinsic factor antibody methods $(r=0.99, p<0.001)$ was excellent, and the calculated regression line $(y=0.88$ $x+7.9$ ) was not significantly different from the line of identity $\left(45^{\circ}\right)$. The correlation of the results between staphylococcal protein A-Sepharose and Cbi methods was similar $(r=0.97, p<0.001)$, and the calculated regression line $(y=0.85 \times+8.5)$ was not significantly different from the line of identity $\left(45^{\circ}\right)$.

The two control gastric juice samples were assayed repeatedly. Using four different assays based on completely different principles, the results obtained were similar (table 2).

\section{SCREENING SERA FOR BINDING ANTIBODY}

Thirty sera from control subjects were screened and found to be negative. Of the 15 patients with intrinsic factor blocking antibody in their serum, six had intrinsic factor binding antibody.

\section{Discussion}

In this study staphylococcal protein A coupled to Sepharose was used to measure intrinsic factor and its binding antibody. The antibody interaction with antigen was linear at low concentrations, which agrees with the results of previous work done in this laboratory ${ }^{4}$ and is similar to the interaction of the blocking antibody to intrinsic factor. ${ }^{\prime}$ Furthermore, excess antibody, up to 10 -fold the amount required to saturate intrinsic factor hardly influenced the results intrinsic factor activity in gastric juice from normal
Table 2 Comparison of intrinsic factor results by three different assay methods (results expressed in terms of $\mathrm{Cbl}$ bound to intrinsic factor, $\mu \mathrm{g} / \mathrm{l})$

\begin{tabular}{|c|c|c|c|c|}
\hline & $\begin{array}{l}\text { Blocking } \\
\text { antibody }\end{array}$ & $\mathrm{Cbi}$ & $\begin{array}{l}\text { Staphylococcal } \\
\text { protein A }\end{array}$ & $\begin{array}{l}\text { Gel } \\
\text { fltration }\end{array}$ \\
\hline $\begin{array}{r}\text { Gastr } \\
1 \\
2 \\
3 \\
4 \\
5 \\
6 \\
7 \\
8\end{array}$ & $\begin{array}{c}\text { juice from } \\
166 \\
99 \\
104 \\
113 \\
96 \\
95 \\
136 \\
73\end{array}$ & $\begin{array}{c}y \text { subject } \\
164 \\
115 \\
107 \\
118 \\
95 \\
99 \\
136 \\
73\end{array}$ & $\begin{array}{r}162 \\
92 \\
101 \\
103 \\
89 \\
92 \\
120 \\
76\end{array}$ & \\
\hline $\begin{array}{c}\text { Contr } \\
9 \\
10\end{array}$ & $\begin{array}{l}\text { gastric jui } \\
106 \\
47\end{array}$ & $\begin{array}{c}\text { m health } \\
110 \\
45\end{array}$ & (s) $\begin{array}{r} \\
105 \\
52\end{array}$ & $\begin{array}{r}105 \\
50\end{array}$ \\
\hline $\begin{array}{c}\text { Gastri } \\
11 \\
12\end{array}$ & $\begin{array}{l}\text { ice from } \\
0.85 \\
<0.5\end{array}$ & $\begin{array}{r}\text { with pe } \\
0.8 \\
<0.5\end{array}$ & $\begin{array}{c}\text { maemia } \\
0.80 \\
<0.5\end{array}$ & \\
\hline
\end{tabular}

subjects and patients with pernicious anaemia measured by this assay closely correlated with the results of two established assays. ${ }^{23}$ This is particularly relevant as the two assays ${ }^{23}$ are complementary: one measures the intrinsic factor activity in gastric juice by determining the drop of $\mathrm{Cbl}$ binding in gastric juice using blocking antibody which blocks the attachment of Cbl to intrinsic factor; the other uses cobinamide ${ }^{3}$ which blocks the attachment of $\mathrm{Cbl}$ to $\mathrm{R}$-protein present in gastric juice and measures the binding of intrinsic factor directly.

In a group of 15 patients with pernicious anaemia with positive blocking antibody six $(40 \%)$ were also found to have the binding antibody, which was slightly 
higher than the average incidence $(33 \%)$ expected in patients with pernicious anaemia tested at random. ${ }^{16} 17$ The binding antibody could not be detected in any of the control subjects.

The advantage of this method of assay is that it can measure radioactive and potentially non-radioactive Cbl-bound intrinsic factor which facilitates binding studies of $\mathrm{Cbl}$ to intrinsic factor, carried out under different conditions, such as $\mathrm{pH}$ and proteolytic enzymes. This may be of particular value in investigating further the aetiology of $\mathrm{Cbl}$ malabsorption in pancreatic insufficiency and the mechanism by which bicarbonate and pancreatic proteases are necessary to degrade partially $\mathrm{R}$-protein and enable $\mathrm{Cbl}$ to be bound exclusively to intrinsic factor. ${ }^{18}$ Furthermore, screening patients for binding antibody to intrinsic factor eliminates false positive results caused by high serum $\mathrm{Cbl}$ concentrations, which can be a problem with the blocking intrinsic factor antibody test. It is predicted that in patients in whom serum IgG is greatly increased, falsely low results may be obtained. Work is in progress to develop an assay for serum $\mathrm{Cbl}$ using this technique.

The method is simple, sensitive, and accurate and suitable for use in any clinical laboratory using radioisotopes.

I thank Drs John Burman and John Amess of St Bartholomew's Hospital for providing the clinical data and blood samples. I also acknowledge Professor Alan Waters (St Bartholomew's Hospital) for many useful discussions and Mr James A Begley of the Veterans' Administration, Albany, New York for his helpful comments and suggestions.

\section{References}

1 Ardeman S, Chanarin I. A method for the assay of human gastric intrinsic factor and for the detection and titration of antibodies against intrinsic factor. Lancet 1963;ii:1350-4.

2 Gottlieb C, Lau KS, Wasserman LR, Herbert V. Rapid charcoal assay for intrinsic factor (IF), gastric juice unsaturated $\mathbf{B}_{12}$ binding capacity, antibody to IF, and serum unsaturated $B_{12}$ binding capacity. Blood 1965;25:875-83.
3 Begley JA, Trachtenberg A. An assay for intrinsic factor based on blocking of the $\mathbf{R}$ binder of gastric juice by cobinamide. Blood 1979;53:788-93.

4 Jacob E, O'Brien HAW. A simple assay of intrinsic factor-vitamin $B_{12}$ complex employing the binding intrinsic factor antibody. J Clin Pathol 1972;25:320-5.

5 Grasbeck R. Intrinsic factor and the other vitamin $B_{12}$ transport proteins. In: Brown EB, Moore CV, eds. Progress in haematology. Vol VI. New York: Grune and Stratton, 1969:233-60.

6 Rothenberg SP. A radioimmunoassay for human intrinsic factor. $J$ Lab Clin Med 1966;67:879-90.

7 Grasbeck R, Wahlstedt V, Kouvonen I. Radioimmunoassay of urinary intrinsic factor. A promising test for pernicious anaemia and gastric function. Lancet 1982;i:1330-2.

8 Marcoulis G, Rothenberg SP. Functional activity of intrinsic factor measured by using solubilized receptor protein. Clin Chem 1982;28:1794-6.

9 Kronvall G, Seal US, Finstad S, Williams RC Jnr. Phylogenetic insight into evolution of mammalian fragment of $\gamma \mathrm{G}$ globulin using staphylococcal protein A. J Immunol 1970;104:140-7.

10 Langone JJ. ( $\left.{ }^{125} \mathrm{I}\right)$ protein $\mathrm{A}$ : a tracer for general use in immunoassay. J Immunol Methods 1978;24:269-85.

11 Allen RH, Seetharam B, Allen NC, Podell ER, Alpers DH. Correction of cobalamin malabsorption in pancreatic insufficiency with a cobalamin analogue that binds with high affinity to $R$ protein but not to intrinsic factor. In vivo evidence that a failure to partially degrade $\mathbf{R}$ protein is responsible for cobalamin malabsorption in pancreatic insufficiency. $J$ Clin Invest 1978;61:1628-34.

12 Gullberg R. Separation and immunologic characterisation of hog intrinsic factor in comparison with human intrinsic factor. Acta Medica Scandinavica 1966;180:317-28.

13 Ey PL, Prowse SJ, Jenkin CR. Isolation of pure $\operatorname{IgG}_{1}, I_{g G} a$ and $\mathrm{IgG}_{2} \mathrm{~b}$ immunoglobulins from mouse serum using protein $\mathrm{A}$ Sepharose. Immunochemistry 1978;15:429-36.

14 Anderson BB, Sourial NA. The assay of serum cobalamin by Euglena gracilis. In: Hall CA, ed. The cobalamins. Vol 10. Edinburgh: Churchill Livingstone, 1983:51-64.

15 Hansen $\mathrm{HJ}$, Miller $\mathrm{ON}$, Tan $\mathrm{CH}$. Assay of the autohumoral antibody that neutralizes the vitamin $B_{12}$ combining site of intrinsic factor in serum from patients with pernicious anaemia. Am J Clin Nutr 1966;19:10-6.

16 Glass GBJ. Gastric intrinsic factor and other vitamin $B_{12}$ binders. Biochemistry, physiology, pathology and relation vitamin $B_{12}$ metabolism. Stuttgart: George Thieme, 1974:29-44.

17 Donaldson RM. Mechanisms of malabsorption of cobalamin. In: Babior BM, ed. Cobalamin biochemistry and pathophysiology. New York: John Wiley and Sons, 1975:335-68.

18 Allen RH, Seetharam B, Podell E, Alpers DH. Effect of proteolytic enzymes on the binding of cobalamin to $R$ protein and intrinsic factor. In vitro evidence that a failure to partially degrade $R$ protein is responsible for cobalamin malabsorption in pancreatic insufficiency. J Clin Invest 1978;61:47-54. 